\title{
THE ISRAELITE RELIGIOUS CENTRE OF KUNTILLET 'AJRUD, SINAI
}

\section{Zev Meshel}

\section{THE SITE}

Kuntillet 'Ajrud (Horvat Teiman) is located about halfway between the Mediterranean and the Red Sea (Gulf of Eilat), forty miles south of the Biblical Kadesh Barnea (Fig. 18). It sits on a flat hill which rises beside the water wells of Wadi Quraiya.

Old maps reveal that the site is a crossroads of desert tracks: one leads from Gaza to Eilat; another traverses the Sinai along the Wadi Quraiya; and the third branches off to the south, to the centre of southern Sinai.

The site was discovered by the famous English explorer Edward Palmer who surveyed the Sinai in the 1860 s and visited 'Ajrud in 1869. There he carried out a small sounding into the ancient remains and subsequently identified the site as Gypsaria, a site known from Roman sources as a station on the Roman road from Gaza to Eilat.

Our excavation revealed that the ruin is a one-period site. All the remains belonged to one phase in the Iron Age - about 800 B.C.

The site contains the remains of only two structures (Meshel 1978: $9^{\prime}-12^{\prime}$ ): a main building at the western extremity of the plateau and a smaller building east of it (Fig. 19). The two buildings are in a very different state of preservation. Almost nothing is left of the latter. The main building, whose walls have survived to a height of five feet, measures approximately $75 \times 45$ feet, and takes up the whole width of the narrow plateau (Pl. 34).

The entrance to this building is from the east, through a small court with stone benches along the walls. Fragments of frescoes found amidst the debris on the floor of the entrance indicate that parts of the walls were painted with colourful floral motifs and linear designs. An entryway led from the small entrance court to a long, narrow room, which we named the "Bench-room". Both the Bench-room and the entry had benches along the walls and were plastered all over with white, shiny plaster.

The Bench-room extends across the width of the building. The 
benches along the walls on each side of the entryway take up most of the floor space, leaving only a narrow passage between them. The inner courtyard was empty except for three ovens found in each of the southern corners, indicating that this was probably the cooking area. Steps were found in the same corners. They probably formed part of staircases leading to the roof.

To the south and west of the courtyard were two long rooms. In the floor, bases of pithoi, or storage jars, were firmly embedded and so closely spaced that it must have been difficult to pass between them. There is no doubt that these rooms were used for storing food.

\section{THE INSCRIPTIONS}

The most remarkable finds of the excavations were the inscriptions and drawings. Most of these were found in the Benchroom and in the two side rooms entered from the Bench-room. Most of the inscriptions were fragmentary and incomplete, but the written word always has a special significance, particularly in such a remote site. The inscriptions, most in early Hebrew and some in Phoenician script, can be divided into several categories (Meshel 1986): 1) Letters or words incised on stone bowls and pottery before firing. These are Sighn Tithe and offerings which were sent to the priests who inhabited the site and vessels which were dedicated to this place by donors, who asked for divine blessing. 2) Inscriptions written in black or red ink on plaster. - These consist of requests, prayers and blessings to and by "Yahweh of Teiman and his Ashera", "El", "Ba'al" (Meshel 1979: 31).

3) Inscriptions incised or written in ink on pottery vessels after firing. - These are accompanied by drawings and reflect a formula of blessing "By Yahweh of Samaria and his Ashera".

The inscriptions (and other finds) shed important light on the nature of the site as a kind of religious centre or a way-side shrine.

\section{THE DRAWINGS}

Due to its plan and the absence of any cultic vessel we do not think that the building was a temple. But the meaning of the inscriptions, as we saw, is very clear. Some of them were written beside many drawings. Do they have the same meaning? Do they have a religious or cultic significance?

The drawings and decorative designs can be distinguished in the following categories (Beck 1982: 3-64): 1) Coloured fresco designs. - These are fragments of decorated plaster which were found in the 
debris of the eastern building and at the entryway of the main building. Most of them are of geometrical patterns but there is a scene of a figure seated on a throne holding a lotus flower, and another one showing two figures on a city wall. These two scenes of the wall-paintings may have a religious meaning. 2) A coloured scene of a human head, goat and lotus flower on one of the stones in the jamb of the central opening to the southern store-room. 3) Drawings on various pottery vessels, particularly on two large pithoi, many of which (unpainted) were found in the store-rooms. These two were found in and near the Benchroom (Figs. 20-21). The main scenes, painted in red ink, are: cow-andcalf, ibexes flanking a tree-of-life, a lion, a procession of animals, two Bes figures and a lyre player, procession of worshippers, a boar, a seated figure and some more (Beck 1982).

The drawings were painted by three or four painters. At least one of them was familiar with the most common motifs prevailing in the Near East. The iconographic sources of inspiration lie in the Phoenician world and the regions of north Syria. Do they have a cultic meaning?

\section{CONCLUSION}

The drawings cannot be separated from the inscriptions and other finds of the site. They parallel and complement each other. They do have, in our opinion, a cultic significance, in the general wide meaning of this concept. The exact symbolism of each scene is a subject of another paper.

\section{Summary}

Kuntillet 'Ajrud, on the Negev-Sinai border, is a religious centre or a way-side shrine from about 800 B.C. The site contains a main rectangular building with a white plastered Bench-room, in which most of the finds were made. The most important of these are inscriptions and drawings on pottery vessels, on wall plaster and stones. The motifs of the drawings are closely connected with the inscriptions and other finds which clearly have a religious character. They too have, in our view, a cultic meaning. 


\section{Bibliography}

BECK, $P$.

1982 - The drawings from Horvart Teiman, Tel Aviv, 9, no. 1, pp. 3-68. MESHEL, Z.

1978 - Kuntillet 'Ajrud, a Religious Centre from the time of the Judaean Monarchy on the Border of Sinai, The Israel Museum, Cat. no. 175, Jerusalem.

1979 - Did Yahweh have a consort?, BAR V, no. 2, pp. 24-35.

1986 - The finds of Horvat Teiman (in Hebrew), Sinai, Tel Aviv (forthcoming). 